Pickerill, $J$ and Webster, F. 2006. 'The Anti-War/Peace Movement in Britain and the conditions of Information War' International Relations, Vol.20, No.4: 407-423

\title{
The Anti-War/Peace Movement in Britain and the conditions of Information War
}

\author{
Jenny Pickerill and Frank Webster
}

Jenny Pickerill is Lecturer in Human Geography at the University of Leicester, and Frank Webster is Professor of Sociology, City University London. We would like to acknowledge the support of the ESRC (RES-228-250060).

\begin{abstract}
Using the concept of Information War we explore the conditions and mediation of contemporary war. Examples from British anti-war and peace movements are then employed to better understand the importance of 'symbolic struggles', focusing on the importance of the internet, in recent opposition to military action. These examples signify a shift away from the era where the mediation of war could be closely controlled towards one where the influences of journalists and public opinion are more ambiguous and uncertain. While there is little doubt that those who wage war remain powerful and superior, their need to seek legitimacy amongst their publics and the use of new media provides an environment through which voices of dissent can more easily be amplified.
\end{abstract}

\section{Introduction}

On $15^{\text {th }}$ February 2003 an estimated 1 million people took to the streets of London to protest against the imminent war with Iraq (BBC, 2003). On the third anniversary of the war, $18^{\text {th }}$ March 2006, thousands once more lined the streets demanding an end to the occupation (Figure 1). These protests, and the multiple actions that have taken place in between, represent an upsurge in peace campaigning in Britain and worldwide.

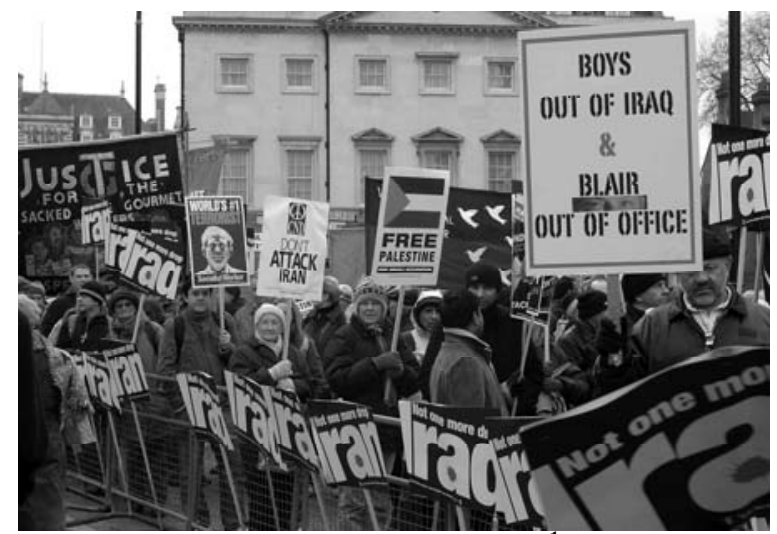

Figure 1: London anti-war rally ${ }^{1}$

The main concern of this article is with distinguishing features of contemporary war.

To understand the relation between the military battles, political consequences and anti-war dissent we employ the concept of Information War. We are particularly interested in the role of the internet in the symbolic presence and efficacy of those groups mobilising against war and for peace. Moreover, we concentrate on activism in the minority world and, in terms of examples, on British groups and mobilisations, and are thus exploring the contestation of

\footnotetext{
${ }^{1}$ All photographs are by Pickerill and were taken on the London anti-war rally $18^{\text {th }}$ March 2006
} 
Information War from this specific context. Thus we focus, for reasons explained below, on the construction of 'symbolic struggles' between those who support war and those who oppose it. Overall, we argue that anti-war and peace groups have been able to take advantage of the shift towards Information War, and of communication technologies such as the Internet, in playing an important role in contesting government aims and legitimacy in waging war.

\section{Part One - Information War ${ }^{2}$}

To account for these circumstances we deploy the concept of Information War (Tumber and Webster 2006). It has two major dimensions: weaponry that incorporates the most advanced computer communications technologies available and a vastly expanded symbolic realm where media of all sorts play a vital role. Information War weaponry is exemplified in 'fire and forget' missiles, in 'precision targeting', and in an abundance of air power from which to launch attacks. Information War in its symbolic dimensions is manifest in round the clock news reporting, the presence of hundreds and even thousands of journalists in the war zones, and in internet communications ranging from e-mail to blogs. These dimensions operate in Joseph Nye's (2005) terms of 'hard' and 'soft' power: Information War weapons are hard is so far as they disable and destroy identified enemies; Information War symbols are soft in that they are concerned with meanings and understanding. Both are essential for the conduct of contemporary war, with the former most important in the early stages, though the latter vital if a force is to prevail longer term. In this essay we focus attention on the symbolic realm and the role of the anti-war and peace movements in the contestation of Information War.

For those who see Information War from a defence perspective the issue is largely technological. There has been a 'Revolution in Military Affairs' (RMA) (Cohen 1996; Berkowitz 2003) that accompanies the microelectronics revolution of the 1980s. Digitalisation is the order of the day, massively empowering military capability. Only a limited number of nations are able to take full advantage of the RMA, but the USA dwarfs any other presence. Information War capability in terms of weaponry means that, when such forces enter a war situation, it will be quickly over. So long as the enemy is identifiable, it will be overwhelmed by the superiority of the military with access to Information War weapons. For this reason Manuel Castells (1996) refers to the development of 'instant wars' (pp.454-61), since hard fighting will be over in a matter of weeks or months. Waged predominantly from the air, enemies will crumble irrespective of the battle experience, discipline or courage of their troops. However, while possession of weapons saturated with information and communications technologies means that an enemy's forces may quickly be destroyed, occupation is a different proposition. In circumstances in which infantry must be on the ground they are susceptible to low grade assault such as roadside bombs and ambush. It is this that has confronted the American and British forces in Iraq. The formidable Republican Guard was incapable of resisting the waves of air and missile attack in March 2003, but so-called insurgents have been able to cause enormous problems for the occupying armies.

If superiority and massive asymmetry in terms of weaponry explains the rapid 'victory' in Iraq, and the vulnerability of occupation can account for continued casualties, there are other dimensions to Information War that are of major consequence. One important set of features stems from the changed character of the military personnel who conduct Information War.

\footnotetext{
${ }^{2}$ The following draws on research undertaken with Howard Tumber and owes much to his work (Tumber and Webster 2006). We would like to acknowledge the support of the ESRC for this earlier project (RES-223-250033)
} 
What are required now are not massed ranks of infantry, but what Alvin and Heidi Toffler (1993) call 'knowledge warriors' - the cadre of technically skilled and highly trained experts who fly airplanes and handle surveillance and missile systems. This trend towards professionalised military forces means that the conscription required to ensure the huge numbers of personnel needed at a time of Industrial War (Tumber and Webster 2006) can be dispensed with. In turn this encourages the development of what Martin Shaw (1991) has called a 'post-military' society, one in which high tech orientated forces may be removed to the periphery of the wider society. In the days of Industrial War (broadly 1914-1990) most young men directly experienced military service and it was commonplace for citizens to encounter soldiers and sailors moving to and from bases and homes. In the era of Information War it is much less usual to encounter military personnel in everyday life, and still more rare to undergo service itself. Moreover, while Industrial War required a good deal of industrial effort to address military needs (and in wartime just about everything would be dedicated to the war effort), Information War requires only that the leading edges of computer science, electronic engineering and aerospace businesses be linked to the military.

Finally, the professionalisation and reduction in size of the forces that conduct Information War contributes to the spread of what Edward Luttwak (1996) termed 'post-heroic' military policy, meaning that there is an increased reluctance to incur losses in battle, the preference being for a strategy of overwhelming the enemy with heavy bombing before ground troops are committed. The staggering losses in the days of Industrial War, when massed ranks of troops confronted one another in particular places and endured casualties in the tens of thousands are now avoidable.

\section{Globalised Capitalism}

Conditions pertaining today mean that wars in the minority world are likely to be fought well away from domestic centres in ways that barely impinge upon everyday life. The collapse of communism, and the victory of the capitalism, has encouraged the spread of globalisation, such that we can have what Manuel Castells (1996) has called 'planetary action' in 'real time', whether it is the realm of corporate decision-making, e-mail exchanges, entertainment services, or trading in currencies. A corollary of capitalism's triumph has been a decline in the significance of territory, notably that of the nation state. Industrial War revolved around conflicts over borders and sovereignty over land. Globalisation, plus the capacity to move capital and coordinate affairs across time and space irrespective of governments, means that a prime cause of Industrial War is weakened (Howard, 2001). Wars between nations have not disappeared, but there has been a remarkable decrease in the likelihood of nations coming to arms.

One area in which there has been an increase in armed conflict has come from international terrorism, there being 'a dramatic increase in the number of high-casualty attacks since the September $11^{\text {th }}$ attacks on the US in 2001' (Human Security Report 2005, p.2). Most famously in the case of Al-Qaeda that announced in 1998 'Jihad Against the Jews and Crusaders', these and like-minded 'enemies without states' (Giddens 1994) have instigated more than thirty major attacks in over a dozen countries that have accounted for over five thousand deaths and many more injuries. This form of terrorism causes considerable public alarm, but compared to the killings in Industrial War the number of deaths are scarcely significant. The greatest fear is that such groups might gain access to biological or chemical weapons that could wreak havoc in metropolitan centres. Accordingly, a prominent feature of Information War - intensive levels of surveillance and intelligence gathering - is focussed on groups that might harbour active terrorists of this sort. 


\section{The Mediation of War}

The foregoing has emphasised that Information War sidelines the military in societies, from experience of service to the conduct of battle. Information Wars are short and sharp so long as enemies are identifiable, massively asymmetrical, and undertaken by professionalised and high tech military forces. In addition, wars have declined over recent decades, markedly so since the end of the Cold War and the accelerated globalisation that has succeeded this. To be sure, conflicts have not disappeared and indeed the triumph of market principles and practices can contribute to the dislocation that feeds much conflict today. The question then arises, how might we account for, and what is the significance, of widespread perceptions that war is on the increase and that armed conflict is threatened pretty much anywhere? This takes us unavoidably to a second major feature of Information War, the symbolic sphere.

A major feature of Information War is saturation media coverage. This is not only pervasive, it is also continuous on 'rolling news' channels such as CNN and BBC World, and it is present too in e-mail communications, internet web sites, and on list serve groups. The most important medium remains television, but it too is transforming with digitalisation and globalisation, to enable a much greater variety and quantity of information about war. This might be contrasted with media in Industrial War. Then media, especially radio and newspapers, was important to the war effort, but it was readily conscripted to the national effort and censored if necessary.

Nowadays wars are removed from the direct involvement of most people, yet at the same time citizens experience vastly expanded second hand knowledge of war, through intensive and extensive media coverage. In conditions of Information War the general public are spectators of events at a distance, though much of this experience may be vivid and immediate (the journalist reporting live to camera from a distant conflict zone is a commonplace occurrence now). This is another reason why 'post heroic' war is a priority for the military command the public get each death in combat reported, often in considerable detail, with testimony from grieving parents and other loved ones - and this can have a significant impact on domestic and even international support for the war. ${ }^{3}$

In conditions of Information War journalists swarm to trouble spots, drawn by the news value of covering the most dramatic events imaginable, where history is in the making and events literally involve life and death. From such locations, as conflict builds, often thousands of journalists file reports round the clock. Places like Kabul and Fort Stanley, Fallujah and Nablus become familiar to audiences who previously scarcely knew of their existence. They receive a regular, sometimes indigestible, diet of news and comment from many locations where 'bad news' may be found. This is one major reason why publics in advanced regions perceive the world to be especially troubling.

The Internet-connected and television-watching public that has access to this continuous information flow may become more knowledgeable of what is taking place than those on the ground, something observed by numerous journalists covering the Iraq invasion. For example,

\footnotetext{
2 Consider in this respect the Military Families Against the War group www.mfaw.org.uk Members have achieved significant media coverage in the UK. Reg Keys, father of Thomas who was killed in June 2004 in alMajar, contested Tony Blair's seat in the 2005 general election. In the United States a comparable campaign involved Cindy Sheehan, mother of a soldier killed in Iraq, demonstrating outside the Texas ranch of the President (Gupta, 2006).
} 
James Meek, Foreign Correspondent of the Year in 2004 for his coverage of the Iraq War, added that because reporters with the military did not have access to the cumulation of disparate reports that were available to listeners, readers and viewers in the UK, he felt 'I missed the war because I hadn't seen it on TV' (quoted in Greenslade, 2003).

This intensive mediation of Information War means, of course, that the military forces devote a good deal of energy to its management. That is, at root, what embedding journalists is about, attempting to ensure that journalists are with the military in mind as well as in body.. The easiest thing for the military to do is exclude journalists from the theatre of war, hence avoiding the possibility of photographs of allied dead, atrocities inflicted on civilians, or even frightened and confused soldiers. However, this is not an option, at least over any length of time, in circumstances of Information War since legitimacy of war requires the presence of journalists. When journalists are excluded, as for instance they were when the Israeli Defence Force (IDF) led an assault on Jenin and Nablus in April 2002, then the exclusion itself becomes the story. What resulted from the IDF's decision was counter productive criticism of the Israelis, credence even being given in the world's media to allegations of a 'massacre' taking place.

It is a delicate balance to achieve: the military want to prosecute the war effectively while ensuring a steady stream of (positive) media coverage that is ostensibly freely gathered by independent and unhindered journalists. However, we would emphasise that in circumstances of Information War the military rarely succeeds in controlling the information environment. There are several reasons why this is so (Tumber and Webster 2006):

1. The enormous number of journalists that converge on trouble spots, numbering often in the hundreds and even thousands, means that they can be hard to control.

2. The location of journalists makes it hard to determine the news. Once journalists followed the militaries' side; nowadays there is usually a media presence beside and even behind the enemy.

3. The diverse international composition of the journalist body means that the traditional moral force of 'backing your country' is weakened.

4. The professional values of front line correspondents, which combine cynicism towards sources with a commitment to 'get the story', mean that they are acutely aware of efforts to control them and they respond accordingly.

5. The access of journalists to light weight and versatile technologies - essentially the laptop and satellite phone - means they can report direct to their headquarters from pretty well anywhere.

6. The widespread availability of the Internet allows journalists themselves to access others' reports and alternative information readily, and then to inform their own reports as appropriate.

7. The spread of e-mail and blogging means that there are occasions in which it is hard to hold to narrow definitions of the media. For instance, the 'Baghdad Blogger', the architect Salem Pax posted an online diary during 2003 recounting his experiences inside a city under bombardment. This in turn became a source of news for wider media outlets.

8. The presence of alternative newsmakers, notably the Arabic agency Al Jazeera, means that alternative reports are made available on a wide basis (it is not insignificant that Al Jazeera offices were attacked by US forces in both Afghanistan and Iraq).

9. Sources of information are not restricted to the conflict zone. They come from many locations, from cities across the world, from government spokespeople, from lobby 
groups and campaigners, all ensuring that the information environment is both enormously expanded and contested.

10. There can be division within the mainstream media, thus opening up the range and degree of information from and about the war. During and after the 2003 Iraq invasion, for instance, the Independent and the Daily Mirror newspapers opposed the sending of troops and made much space for dissent.

The upshot of this is that however much military forces plan for Information War by developing strategies for handling correspondents, there will be much that is unplanned and undesirable from the perspective of the military. Nothing more vividly evidences this than the hundreds of photographs from Abu Graib prison in April 2004 showing American personnel abusing, taunting and even torturing prisoners with savage dogs and electricity charges. These photographs, taken on digital cameras and transmitted easily through e-mail connections, have become defining images that have undermined the war effort.

\section{Legitimacy and Challenge}

Public engagement with war may be acutely intensive albeit that it is mediated. The symbolic dimensions of war are vital to its conduct, yet there is such a degree of media coverage, so many alternative sources, and such problems of controlling information flows, that no-one may be confident of having their preferred messages transmitted straightforwardly. Moreover, the symbolic environment involves even more than media messages - however broadly we may conceive of media to include blogging, e-mails and the like - from war zones. Many things contribute to what Martin Shaw (2000) describes as 'globality', a 'common consciousness of human society on a world scale' (pp.11-12). These range from media exposures of atrocities to frequency of travel to foreign parts, from encounters with diverse cultures through migration to experiences of different forms of music and cuisine, from the agitation of NGOs such as Third World First and Human Rights Watch to the campaigning of Amnesty International (Brysk 2002). This expanding consciousness usually finds a place in the discourses of Information War.

It is remarkable how much those who support Information War, eager to establish legitimacy with their publics, recourse to a language of democratisation and human rights (Diamond 2003). It is a language much evident during the First Gulf War, the NATO intervention in Kosovo, the regime change brought about by British troops' involvement in Sierra Leone, and the assault on Afghanistan to overthrow the Taliban in 2001. Significantly it was underplayed in the build up to the 2003 invasion of Iraq, when the favoured theme was Weapons of Mass Destruction (Figure 2). Since the invasion, however, it has been a repeated refrain that democracy must be built in that country and elections in Iraq, achieved in grim circumstances, have been greeted with acclamation.

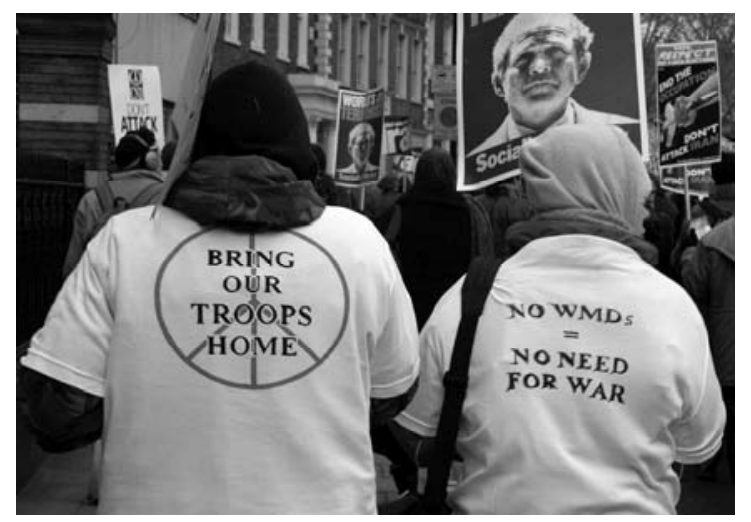


Nowadays there is widespread, if uneven, recognition that there are limits to the view that what takes place inside a nation's territory overrides rights of common humanity. When we attempt to conceptualise this we need to take cognisance of what Craig Calhoon (2004) describes as an embryonic transnational public sphere, the growing presence of sources of information and argument that transcend national divides. This comes about because people in the minority world are able to travel more easily, because migration is vastly increased, because in our metropolitan centres differences are palpable, as well as because there in a communications network capable of ensuring flows of information across national frontiers. This sphere means that individuals have access to Al Jazeera (in English if necessary) as well as Fox News, to BBC World as well as a favoured blog.

Information War is conducted in this environment. Many factions in this war endeavour to control what gets made available, and there are clearly priorities in terms of favoured media spaces that military groups and governments try to influence. In the UK television news and the major newspapers are high on any list of preferred outlets - though such is the shifting information terrain that a story may be announced on a web site and force its way into more mainstream outlets. For example, the searing 'video beheadings' that emerged from Iraq during 2004-5, put out initially on Islamic militants' sites and soon easily accessible on western web sites where they drew record hits. Television outlets in the West then took this material and inflected it editing out the actual beheadings, but Abu Musab al-Zarqawi, reputedly behind several of these displays of hostages, could be confident of getting exposure around the globe. In this way, although blogs or certain news outlets might have limited initial viewing, their content can often be reworked and redistributed. This ability to resonate beyond first audiences belies the complexity of Information War, and simultaneously, signifies the potential for marginal voices to broaden their impact.

\section{Part Two - The Anti-War and Peace Movements and Information War}

A key constituent and contributor to this information environment are the anti-war and peace movements. They are an important player in Information War, in so far as they contest and confound the preferred messages of those forces in favour of war. They may not have a place in the theatre of war itself ${ }^{4}$, but they contribute to the symbolic environment that helps shape how people understand and make sense of conflicts. They ensure that in conditions of Information War symbolic struggles proliferate (Shaw 2005). There can scarcely be a more vivid illustration of this than the unprecedentedly large demonstrations - extensively covered in established media - mobilised by the anti-war and peace movements against the Iraq War on February $15^{\text {th }} 2003$, days before the invasion actually took place. The demonstrations themselves - the sheer volume of participants, their colourful displays and plenitude of banners - constituted symbolic resistance to the forthcoming war, unambiguously signalling huge concern and opposition about what was about to happen (Tyler 2003).

We may get a deeper appreciation of this contention by understanding more of the breadth and diversity of contemporary opposition to war. It is important to grasp that the anti-war and peace movements are broad and often uneasy coalitions (the largest of which in the UK is the Stop the War Coalition [STWC] and in the US is the United for Peace Justice Coalition $[\mathrm{UFPJ}]$ ) composed of groups with very different histories, cultures, goals and motivations. Given this breadth and diversity it is hard to conceptualise such groups forming a social

\footnotetext{
${ }^{4}$ Save for peace activists such as Norman Kember of Christian Peacemaker Teams who went to Iraq late in 2005 and was held hostage until March 2006.
} 
movement. Although there is commonality in resistance to the Iraq war across all groups, their framing and broader demands differ widely. For example, some groups link their resistance to war to broader anti-imperialist struggles or to a pacifist ideology, while others believe in the necessity of war but that the specific war against Iraq was not justified. Consequently it needs to be considered more as a 'movement of movements' (Kingsnorth 2003), with internal allegiances that cut through and fracture coalitions, than a cohesive movement.

So how might we conceptualise such a diverse collection of groups? We could consider there to be seven broad themes to the British anti-war movement. First we may distinguish along a continuum of peace movement to anti-war. This ranges from an ideological pacificism through to opposition to one side's involvement in a specific conflict. On this continuum we might place at one end organisations such as the Peace Pledge Union and the Religious Society of Friends (Quakers) that have a long history of pacificism. At the other end of the continuum would be the Stop the War Coalition (STWC) that campaigned specifically against the invasion of Afghanistan in 2001, Iraq in 2003 and continues to campaign against a perceived threat of an attack on Iran (see Figure 3) (Murray and German 2005). The STWC leadership also prioritises opposition to Israel because of its treatment of Palestine and support from the U.S. STWC is convened by Lindsay German, a member of the Trotskyite Socialist Workers Party but also draws support from factions of the Labour Party, Respect, Campaign for Nuclear Disarmament (CND) as well as the Muslim Association of Britain (MAB).

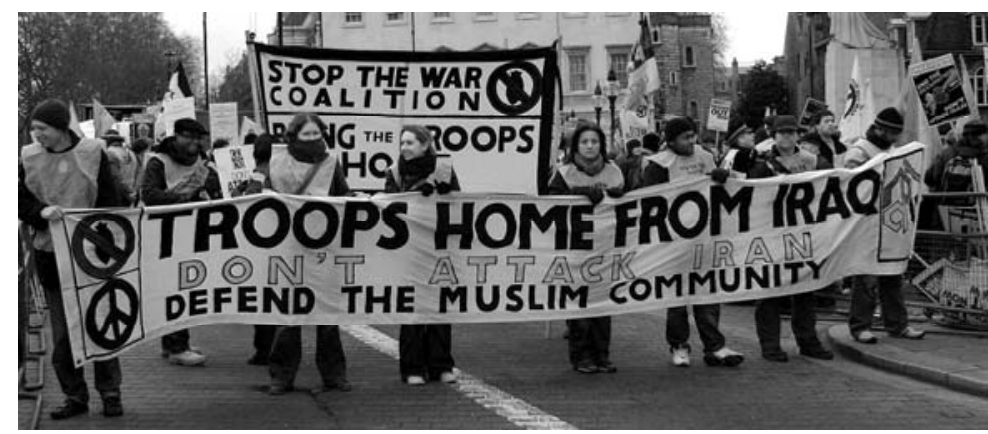

Figure 3: STWC banner

It is also possible to distinguish the peace and anti-war movement in terms of a more or less direct affiliation with political programmes. These cover a substantial range, from the Liberal Democrats to the much smaller Communist Party of Great Britain. The centre of gravity here is the left, with the political party Respect being intimately linked with the anti-Iraq war campaign, and it includes Labour Action for Peace (not affiliated to the Labour Party) and Labour Against the War, convened by MP Jeremy Corbyn. It may also make sense to locate the anarchist group, Wombles, on this continuum, though arguably it expresses an anti-politics outlook.

Then there are feminist or feminist-inspired/influenced groups that have distinctive characteristics and have long played a prominent role in peace activism (notably through the Greenham Common camps in the 1980s). For instance, Women in Black is well established and international in orientation, and though relying heavily on Internet links it also holds regular 'vigils' in specific locations. 
One might also consider religious-oriented organisations. The London-based group JustPeace was an explicitly Muslim anti-war group and the Muslim Association of Britain has been prominent both on anti-war rallies and in providing Muslim orientated perspectives in mainstream media coverage (Figure 4). Women Praying for Peace is also an interesting instance of the conjoining of pacifism and feminist. The Society of Friends is a distinctive pacifist group with long established roots. Moreover, it is evident that CND has contained from its foundation significant Christian activists (Parkin 1968).
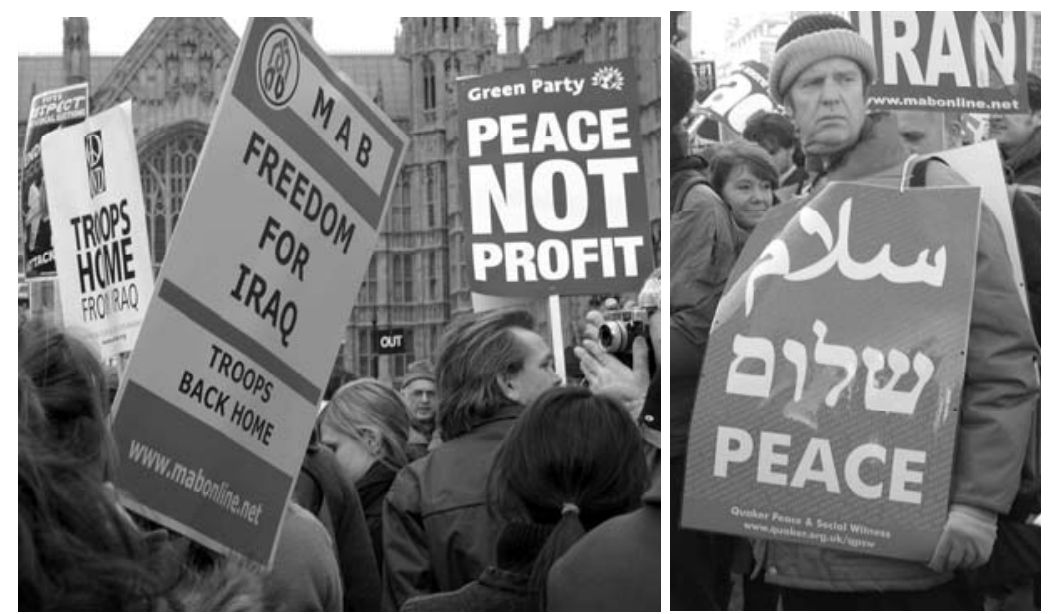

Figure 4: MAB and Quaker poster boards

We need also to distinguish groups along a continuum of organised institutions to loose networks. Some are strongly centralised and organisation oriented while others are loose, virtual, connections. The Network for Peace might be seen as fitting at one end of this continuum (loosely connected) with Stop the War Coalition at the other (centrally organised). In addition, groups vary in terms of the degree to which they are nationally or internationally oriented.

There are also interesting activist/performance groups that deserve attention, not least due to their emphasis on symbolism. They may offer music, dance or performances in pursuit of peace. Examples include Rhythms of Resistance, Bare Witness and Code Pink (Figure 5). Finally, there is also a distinction between organisations that have a specific remit (e.g. CND being anti-nuclear weaponry; IANSA [International Action Network on Small Arms]) and those that have a broad anti-war remit (such as pacifist groups).

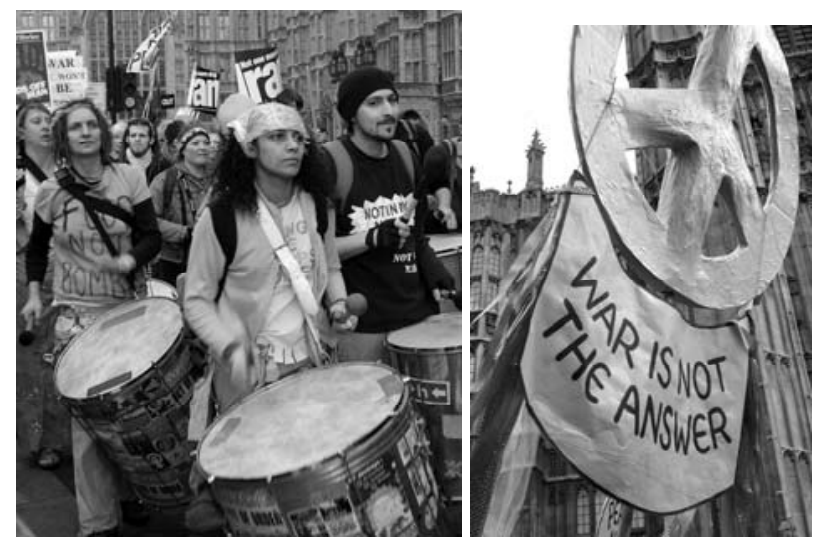

Figure 5: Rhythms of Resistance and Code Pink 
This overview demonstrates that while there appears to be overlap in memberships amongst individuals, we are talking about a diverse range of people and organisations ${ }^{5}$. Collectively they represent a sizeable symbolic force. Moreover, all these groups have adopted, more or less energetically, the new media resources that facilitate their campaigning (Clark and Themudo 2006). Manuel Castells (1996) asserted that activists must be on the internet or be condemned to irrelevance since 'outside the media sphere there is only political marginality' (p.312). A good deal of literature contends that Information and Communication Technologies (ICTs) have been fitted into ongoing patterns of professionalisation of politics in general (carefully planned public relations, marketing strategies, and conscious branding etc) such that continuities are more resonant than change (Diani 2001). We acknowledge this, but also want to signal ways in which the anti-war and peace movement have been able to take advantage of network technologies, thereby enhancing their symbolic presence and efficacy. According to Kahn and Kellner (2004) 'the global internet... is creating the base and the basis for an unparalleled worldwide anti-war/ pro-peace and social justice movement during a time of terrorism, war and intense political struggle' (p.88). Moreover, we can use an examination of ICT use to better understand how such a heterogeneous movement can cooperate and be sustained:

1. All have established web sites for their activities. Even groups with but a handful of active members can set up a web site, create electronic lists of members and sympathisers, establish e-mail contact and be players far beyond the interpersonal. In a short space of time - little more than eight years or so - web sites have become ubiquitous amongst protest movements (Pickerill 2003). Rapidly reducing real costs for campaigners (Bimber 2003) have made entry into a symbolic field easy. Those who access these sites encounter messages ignorant of the size and wider significance of the group that created them (Boyd 2003).

2. E-mail especially, but also web sites and text messaging, have made the coordination of anti-war and peace movements considerably easier, cheaper and more regular. This is illustrated by Berger (2005) who describes her transition from her early involvement in an Aldermaston march in 1958 to using email and text messaging for mobilising for world summits and recent anti-war protests. Organisations can connect internally and nationally in improved ways, but in addition international relations are significantly eased. Much of this coordination, as far as members and sympathisers are concerned, involves announcement of events, chiefly demonstrations and protests of one sort or another (Rheingold 2003). This facility contributed enormously to the global sequencing of protests against the Iraq War before its outbreak, and continued to the March 182006 coordinated protests in well over 100 towns and cities on every continent.

3. While this coordination means that campaigns may 'stretch' across space, there is also a danger of weakening ideological coherence and personal commitment, especially in coalition organisations such STWC, where little is required of those who draw on the website. Bennett (2003) suggests this fits with today's 'lifestyle politics' that are more individualised and fluid than hitherto, a notion that accords with Wellman's (2001) analysis of an emerging 'personalised networking' and 'networked individualism'. Kavada (2005) provides some support with her finding that when it comes to mobilisation to attend a demonstration or protest, then friendship ties and workplace/college relations are more important than Internet links (p.86).

\footnotetext{
${ }^{5}$ In the USA this diversity extends to including military families and veterans (such as Veterans for Peace) which is not as prominent in the British coalitions (Gupta 2006).
} 
4. Networking capabilities may thus be conceived as both a strength and weakness of anti-war and peace campaigners (Bennett 2003). Strength lies in the enormously extended reach of the organisation courtesy of the Internet, a weakness is that receivers may leave the site after only a cursory glance or delete the e-mail without consideration. Chadwick (2006) reminds us of the decrease in persuasive potency of mass e-mail campaigns (p.121) as commentators judged these as requiring little effort from the petitioners. In this way, it can be harder to interpret whether unprecedented large turnouts for anti-war demonstrations really indicate increased opposition to the war or is more a reflection of better anti-war publicity and the ease at which one can attend a legal rally or sign a petition.

5. There are interesting issues here regarding online and offline relationships and their connections with action and consciousness. We cannot yet answer these matters, but it would be a mistake to present these simply as impersonal versus personal since e-mail may be highly individualised, while observing posters on the wall of the university canteen can be an impersonal activity. However, what seems likely is that leaders and the more active members of the anti-war and peace movements are especially active users of the Internet who also have strong interpersonal ties. Kavada (2005) refers to organisations having an 'electronic spine' (p.91) that connects key activists while there is a much broader constituency of people who access the web for information and even receive e-mail.

6. Lance Bennett (2003) coins the felicitous term 'epistemic networks' (p.148) to identify the increased capacity to collect, collate and distribute information through ICTs from disparate locations. On anti-war and peace web sites one finds stored an enormous amount of information, gathered from many sources (from personal testimony to newspaper reports), in support of their case. These reports are framed in different ways (Johnson and Noakes 2005), but we can say that these epistemic networks vastly increase the symbolic resources of protesters.

7. Relatedly, computerisation allows organisation to archive enormous amounts of information about themselves. This may be variously catalogued (e.g. historical, minutes of meetings) and more or less accessible to the public.

8. The web sites contain many links to cognate organisations. This means that sympathisers with any one group may use its web site as a one-stop source for information about anti-war and peace activities. The choice as to which site to use as the first stop will indicate a broad orientation of the user (e.g. it might be a feminist or religious one), but links from there will allow the member to be informed about a wide range of associated organisations. The Network for Peace specifically acts as a linkage point to multiple anti-war organisations.

9. Our preliminary analysis of anti-war and peace web sites suggests that the information presented is not much concerned with persuasion through argument, explanation, or analysis. Rather there appears to be an assumed audience that is already converted to the anti-war and peace message. Because those who access the sites are presumed to share this sensibility, what gets presented is testimony and confirmatory information. For instance, the STWC, while it has a 'News and Analysis' category, concentrates on stories of abuses by the occupying military in Iraq such as killing citizens, beating prisoners and misappropriation of funds. Alternatively, Women in Black gives priority to advertising actions round the world and to recording its history of peace involvement. This may be anticipated amongst campaigning groups, but it is likely to contribute little towards persuading the undecided visitor.

10. New media provide groups with increased flexibility in the symbolic realm, thereby able to conduct 'nimble campaigns' (Bennett 2003, p.145). It also increases the 
durability of organisations (Pickerill 2003). In the anti-war and peace movements, there are obvious peaks and troughs, but ICTs enable speedy adaptation to changing circumstances that increase the life of the movement. For example, as we entered 2006, a major theme on web sites and protests of the anti-war movement has been a perceived threat to Iran from the United States. STWC quickly commenced calling for Iran to be left alone, while a new affiliate site came into being, StopWarOnIran.org, Figure 6.
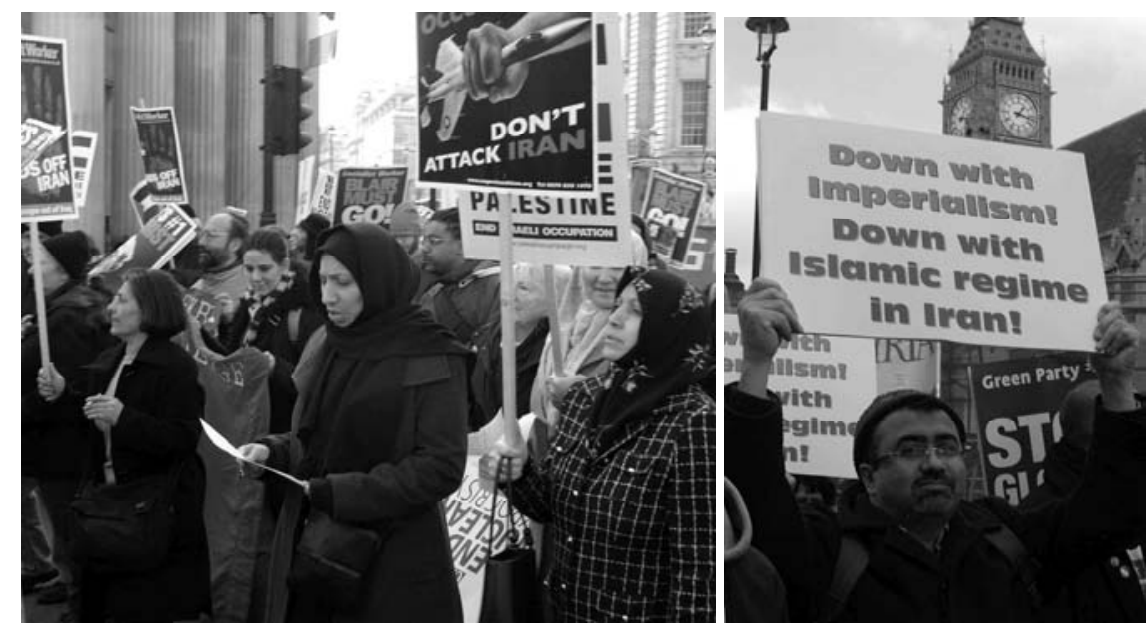

Figure 6: ‘Don’t Attack Iran’ poster board, and ‘Down with Imperialism! Down with Islamic regime in Iran!'

11. As a rule web sites allow space for discussion groups and/or contributions from readers. They are typically aggregated and lengthy exchanges may take place. Blogs may be an element of this process, stimulating exchanges as well as setting out the opinions of leading figures (e.g. as in 'Lindsey's Blog' on STWC). Such facilities offer a degree of interactivity that may enhance engagement with the campaign or organisation, though apart from the aggregation of contributions, these are not radically different from the letters pages of newspapers. It is often unclear the extent of editorial control over such discussion groups, though Kavada's (2005) observation that campaigning web sites still tend to operate with a 'broadcast model of communication' (p.79) suggests limited room for interactivity. Unless groups explicitly adopt an open publishing approach to their use of ICTs, such as the Indymedia global network (Pickerill forthcoming), then control over content and representation is liable to remain in the hands of the more active campaigners of the group.

12. In addition to these more controlled forms of 'apparent' interactivity is the growth of blogs and wikki websites that are not necessarily affiliated to specific campaign groups. Some individuals' anti-war blogs have garnered significant attention on the US political scene (Kahn and Kellner 2004), whereas wikkis enable all users to edit, modify and add information to a central website, a model that has been increasingly adopted by European Social Forums (Pickerill 2006).

13. Internet contributions have a complicated relation to mainstream media. For much of the time they are separate, perhaps used by sympathisers as an information source, but with little evident connection to wider information sources. However, some of the most assiduous readers of web sites are journalists, so it is not surprising to come across instances of Internet information finding a way into daily newspapers. For instance, following Tony Blair's acknowledgment on a television talk show early in 
2006 that he prayed and would be answerable to God for his Iraq policy, there was an extended response on STWC's web site, one contribution of which - from a mother whose son had been killed in Iraq - was reproduced in the Guardian newspaper.

\section{Conclusions}

We have reviewed ways in which the anti-war and peace movement take advantage of a changing media environment to increase their presence and efficacy. However, what we want to highlight is the broader framework of Information War in which symbolic contestation is central, especially in liberal democracies. Those who wage Information War militarily are overwhelmingly superior and sure to prevail in a matter of weeks or months (until occupation is required). However, Information War is also, and indivisibly, about symbolic struggle that lasts much longer than 'hot' battles. Here things are much more ambiguous and uncertain, with journalists hard to control and publics open to a range of conflicting information and interpretation. In this milieu, where governments and military must seek legitimacy for their policies, the anti-war and peace movements play an important role. Whether demonstrating on the streets, lobbying politicians or - as we have stressed in this article - adapting new media to their purposes, these are a constituent element of the information environment that envelops Information War. While these symbolic struggles continue, however, it appears that the words of Sir Henry Maine still ring true: 'War appears to be as old as mankind [sic], but peace is a modern invention' (Quoted in Howard 2001). Despite the changing conditions of Information War the road to attaining peace is as contested, volatile and complicated as ever. We need to further understand not just how to resist war but how to make peace.

\section{References}

BBC News Online (2003) '’Million' march against Iraq war' $16^{\text {th }}$ February, hhtp://news.bbc.co.uk/1/hi/uk/2765041.stm

Bennett, W. L. (2003), 'Communicating Global Activism: Strengths and Vulnerabilities of Networked Politics', Information, Communication and Society 6(2): 143-68

Berger, S. (2005) 'From Aldermaston Marcher to Internet Activist' in W.de Jong, M. Shaw and N. Stammers (eds.), Global Activism, Global Media. Pluto Press

Berkowitz, B. (2003), The New Face of War New York: Free Press

Bobbitt, P. (2002), The Shield of Achilles: War, Peace and the Course of History Harmondsworth: Penguin

Boyd, A. (2003), 'The Web Rewires the Movement', The Nation, August 4

Brysk, A. (ed) (2002), Globalization and Human Rights Berkeley: University of California Press

Calhoun, C. (2004), 'Information Technology and the International Public Sphere', pp.229-52 in Douglas Schuler and Peter Day (eds), Shaping the Network Society Cambridge, MA: MIT Press

Castells, M. (1996), The Rise of the Network Society Oxford: Blackwell

Chadwick, A. (2006), Internet Politics: States, Citizens and New Communication Technologies Oxford Uuniversity Press

Clark, J, D and Themudo, N, S (2006) 'Linking the Web and the Street: Internet-Based "Dotcauses” and the “Anti-Globalization” Movement' World Development, 34, 1, 5074

Cohen, E.A. (1996), ‘A Revolution in Warfare’, Foreign Affairs, 75(2): 37-54

Diamond, L. (2003), ‘Universal Democracy?’ Policy Review 119: 1-28 
Diani, M. (2001), 'Social Movement Networks: virtual and real', pp. 117-28 in F. Webster (ed), Culture and Politics in the Information Age: A New Politics? London: Routledge

Giddens, A. (1994), Beyond Left and Right Cambridge: Polity

Greenslade, R. (2003), 'Fighting Talk', Guardian, 30 June, p.6

Gupta, A. K. (2006), 'Moving Forward: UFPH and the Anti-war Movement' Leftturn Magazine, (19): 64-71

Human Security Report: War and Peace in the $21^{\text {st }}$ century (2005), University of British Columbia: Human Security Centre. Available at www.humansecurityreport.info

Kahn, R and Kellner, D (2004) 'New Media and Internet Activism: From the 'Battle of Seattle' to 'Blogging'’ New Media and Society, 6 (1) 87-95

Kavada, A. (2005), 'Exploring the role of the internet in the 'movement of alternative globalization': The case of the Paris 2003 European Social Forum', Westminster Papers in Communication and Culture 2(1): 72-95

Kingsnorth, P. (2003), One No, Many Yeses: A Journey to the Heart of the Global Resistance Movement London: Free Press

Luttwak, E. (1996), ‘A post heroic military policy’, Foreign Affairs 75(4): 33-44

Morrison, D. and Tumber, H. (1988), Journalists at War: the dynamics of news reporting during the Falklands London: Sage

Murray, A. and German, L. (2005), Stop the War: the Story of Britain's biggest mass movement London: Bookmarks

Nye, J. (2005), Soft Power London: Public Affairs

Pickerill, J. (2003), Cyberprotest: Environmental Activism online. Manchester University Press

Pickerill, J. (2006), 'Radical politics on the net' Parliamentary Affairs, 59, 2

Pickerill, J. (forthcoming), 'Autonomy on-line: Indymedia and practices of alterglobalisation' Environment and Planning A

Poole, O. (2003), Black Knights: On the Bloody Road to Baghdad London: Harper Collins

Rheingold, H. (2003), Smart Mobs: The Next Social Revolution New York: Perseus

Shaw, M. (1991), Post-Military Society: Militarism, Demilitarisation and War at the end of the $20^{\text {th }}$ century Cambridge: Polity

Shaw, M. (2000), Theory of the Global State: Globality as an Unfinished Revolution Cambridge University Press

Shaw, M. (2005), 'Peace Activism and Western Wars: Social Movements in Mass-Mediated Global Politics' in W. de Jong, M. Shaw and N. Stammers (eds.), Global Activism, Global Media. Pluto Press

Toffler, A. and H. (1993), War and Anti-War Boston: Little, Brown

Tumber, H. and Webster, F. (2006), Journalists under Fire: Information War and Journalistic Practices London: Sage

Tyler, P. (2003), 'A New Power in the Streets', New York Times, February $17^{\text {th }}$

Wellman, B. (2001), 'Physical Space and Cyberspace: the rise of personalised networking', International Journal of Urban and Regional Research 25(2) 227-52 